\title{
Handbook on Human Rights in China
}

\author{
Edited by
}

Sarah Biddulph

Melbourne Law School, University of Melbourne, Australia

Joshua Rosenzweig

East Asia Research Director, Amnesty International 


\section{Contents}

List of contributors

List of abbreviations

1 Introduction to the Handbook on Human Rights in China

Sarah Biddulph and Joshua Rosenzweig

PART 1 HUMAN RIGHTS IN CHINA: CONTESTED MEANINGS

2 Human rights in Chinese tradition

Stephen C. Angle

3 Human rights and the political system

Eva Pils

\section{PART 2 INTERNATIONAL DIMENSIONS OF HUMAN RIGHTS IN CHINA}

$4 \quad$ China and the international multilateral human rights system Ann Kent

5 Human rights in Chinese foreign policy: a battle for global public opinion Katrin Kinzelbach

6 China and the 'responsibility to protect' (R2P)

Andrew Garwood-Gowers

PART 3 ECONOMIC AND SOCIAL RIGHTS

7 Subsistence, poverty alleviation and right to development: between discourse and practice

Wim Muller

8 Health and human rights performance in China: stronger on entitlements, weaker on freedoms

Lesley A. Jacobs

$9 \quad$ Labor rights in China

Manfred Elfstrom

10 Examining China's compliance to emerging international norms regarding environmental rights

Anna Brettell

11 Objects of pity or subjects of rights? Disability and human rights in the People's Republic of China

Stephen Hallett 
12 Mental health rights in China

Guo Zhiyuan

13 Women's rights and gender equality in China: the development and struggle in chains of state feminism

Jiang Jue

14 Rights of children and youth in China: protection, provision and participation

Orna Naftali

PART 4 CIVIL AND POLITICAL RIGHTS

15 Freedom of opinion and expression

Hermann Aubié

16 Freedom of religion and belief

Sarah Cook

17 Freedom from torture

Margaret K. Lewis

18 Arbitrary detention

Sarah Biddulph

19 Assessing freedom of peaceful assembly and association in contemporary China

Angeli Datt and Alex Beck

20 The death penalty and human rights in China

Susan Trevaskes

21 Movement and migration

Ming Xia

PART 5 RIGHTS IN/ACTION AND ACCESS TO JUSTICE

22 Lawyers for human rights protection: from legal aid to political lawyering Fu Hualing

23 The right to a fair trial

Elisa Nesossi

24 Transparency, accountability and access to information Jamie P. Horsley

25 The development and obstacles of anti-discrimination law and practice in Mainland China

Lu Jun 
PART 6 POLITICAL DIMENSIONS OF HUMAN RIGHTS IN GREATER CHINA

26 Human rights in Taiwan: a thematic overview Titus C. Chen

27 Human rights and political opposition in Hong Kong Michael C. Davis

28 Rights defense and new citizen's movement Teng Biao

\section{PART 7 NEW FRONTIERS}

29 Human rights and the Internet in China: new frontiers and challenges Marina Svensson

30 LGBTQ rights in China: movement-building in uncertain times Joy Chia

31 Human rights and China's international trade and investment relations Pitman B. Potter

Appendix

Index 


\section{Chapter 1: Introduction}

Sarah Biddulph and Joshua Rosenzweig

It is a daunting assignment to prepare a comprehensive introduction to human rights in China. For one thing, there are several different ways to approach the topic. If one focuses only on the current state of affairs, one risks overlooking the interesting and complex historical journey that China has taken to get there. One also must consider the approach to law and practice, since the compatibility of China's framework of laws and regulations with its obligations to protect, respect and fulfil human rights obligations may look one way on paper and another way when it comes to implementation and enforcement.

The political and social dimensions of human rights are another matter to grapple with. Inherently tied to the relationship between individuals and the state, human rights are intertwined with politics, both in terms of the degree to which human rights are woven into the fabric of institutions and ideologies and in terms of the way that human rights claims by individuals or groups may be mobilized to seek change. Whether you adopt a top-down approach or a bottom-up approach

One also has to decide whether to focus solely on what goes on inside China's borders - a subject complex enough as it is - or take a broader view to encompass both the notion of a 'Greater China' and the different ways that actions taken by China and Chinese entities are having an impact on human rights around the world. One can think of the latter category more concretely, in terms of direct impacts on the ground, or more abstractly, in terms of the influence China is having over the global norms and institutions that govern human rights.

In preparing this handbook, we have tried to account for all of these in some way through a broad array of topics and selection of authors from different fields and backgrounds. Some chapters take a more sweeping, historical approach while others are firmly rooted in things happening in the present day. Some are more focused on legal developments while others are concerned with social action. We have also looked to expand the horizons of what might be considered a more conventional approach to human rights by including discussion of emerging issues.

One also has to consider the matter of tone. Assessments of human rights compliance and performance are always contentious, and they are especially so when it comes to China. Some choose to expose violations and shortcomings in order to seek change. Others choose to focus more on what they see as more positive narratives that highlight China's progress. Some may also try to present the good alongside the bad, but the proper balance between the two is often in the eye of the beholder.

There is one final matter that is impossible for us as authors and editors to control, and that is the ticking clock of time. Any attempt to capture the 'present situation' risks going out of date at some point - sometimes even by the time it appears in print. The chapters in this handbook were prepared during a period when both the international human rights project and China's relationship to it were undergoing many changes. Many authors were understandably concerned about the directions China has taken under the leadership of $\mathrm{Xi}$ Jinping, which have brought serious implications for both China's human rights situation at home and how China approaches human rights on the international level. Though none of us know for sure where these developments will end up, we considered it important to try to make sense of some of the main issues at stake. To help readers to do this, we decided to offer a comprehensive examination both of China's engagement with human rights in international fora and its performance in the domestic arena. 


\section{Objectives of the Book}

As a Handbook, this book has several objectives. It is designed to provide a comprehensive coverage of as many areas of human rights as possible. Each chapter goes beyond a simple overview and introduction to develop the contributor's own analysis and arguments about significant issues within that topic. Where appropriate, chapters provide an outline of the international law in that area, consider domestic engagement with relevant norms and obligations and provide references to relevant literature to enable those interested in that topic to pursue their interest further. Each chapter has been written to be accessible to a wide range of readers, and we intend this handbook to be a valuable reference for both nonspecialists and also specialists in China studies and human rights.

With this handbook we have sought to transcend the battle of competing sloganeering: on one side pointing to China as a chronic human rights abuser and on the other lauding China's achievements in an uncritical manner. As with everything studied carefully and in detail, reality is much more complex.

The contributors to this handbook include a mix of young and established scholars and practitioners from across the world, Chinese and non-Chinese alike, and based both within and outside China. The rich array and diversity of our contributors, we believe, adds to the depth and complexity of perspectives and approaches to examination of China and its engagement with human rights.

We consider it essential to approach evaluation of human rights with a critical eye, and we believe that the authors collected here all reflect this approach. Beyond attempting to maintain consistency of terminology throughout the handbook, our editorial policy has been to allow contributors to express their own views in their own terms, within the bounds of scholarly discourse and conventions. Readers should consider each chapter to reflect the views of its author(s) and not assume that other contributors necessarily agree with everything said elsewhere in the book.

\section{China's Evolving Approach to Human Rights}

China's evolving approach to human rights has been shaped by the various threads of its cultural and political traditions and the distinctive time and manner in which it adapted that traditional inheritance in the process of integrating into the global modern political and economic system - which has of course itself continued to evolve. Angle's chapter reviews the past debates over what relationship can be found between China's traditions (largely influenced by Confucianism) and human rights and finds all of them overly simplistic. As Nathan (1986) and Svensson (2002) have shown, Chinese ideas about state sovereignty, the role of individuals in society and the constitutional relationship between state, society and individuals were deeply influenced by late-nineteenth- and early-twentieth-century utilitarian, positivist and evolutionary theories. The result was an instrumental, legal-positivist way of thinking about rights as a state grant that could be limited and restricted as necessary.

This was the political ethos under which the Marxist class-based notion of rights was applied under Mao Zedong. From the 1949 revolution until around 1980, the idea of 'human rights' was officially rejected as bourgeois, with rights emanating solely from one's membership as part of 'the people' - a politically defined category with ever-changing boundaries. As Pils's chapter shows, many of the legal and political institutions developed during this period persist in contemporary China, which remains under the one-party rule of a Leninist political organization. 
After Mao’s death and under the 'Reform and Opening' initiated by Deng Xiaoping, China began a process of embracing many of the formal aspects of the international human rights system, such as ratification of selected human rights treaties and playing a more active role at the United Nations. Domestically, the 1980s were a period of institution-building, an expanding market economy with global links and a proliferation of legal norms. By untying individuals from many of the controls of the Maoist era, the Chinese government allowed people to experience more freedom and prosperity than they had for decades.

But politically, Chinese institutions did not open up at the same pace. The gap between Chinese society and its political institutions was exposed during the 1989 popular protests in Beijing and other cities that were brought to a brutal end by the bloody military suppression of June Fourth. Internationally, China became an object of human rights scrutiny as it had never really been before. Domestically, the CCP made bolstering its political legitimacy and ensuring its survival a core policy goal. Over the course of the 1990s, China pursued a set of 'stability-first' policies heavily weighted towards preserving Party-state interests. At the same time, however, elaboration of legislation and development of the legal system continued apace in an effort to channel claims and conflict into the legal system.

Chinese leaders went even further during this period to 'domesticate' human rights. This included defanging international human rights criticism by channeling it into bilateral human rights 'dialogue' held behind closed doors while simultaneously building up rhetorical commitments to state-centered theories that bounded human rights within 'national circumstances'. This stage culminated in China's signing of the ICESCR in 1997 (later ratified in 2001) and ICCPR a year later, followed by the inclusion of human rights language in the Chinese Constitution in 2004.

In this situation Chinese people increasingly looked to law and human rights as a resource to frame claims against a state that had publicly embraced those ideas, at least rhetorically. The contradictions between what Chinese people believe they are entitled to, based on principles of equality and citizenship, and the limits of what the Chinese political and legal systems are willing to deliver, contributed to the emergence of a 'rights defense' discourse embraced by lawyers, activists and ordinary people.

The 'rights defense' movement has elevated universal human rights (as opposed to state-centered political rights) as a source of normative power and authority outside the Partystate. By using human rights to make broader claims about the fundamental relationship citizen and state, those who embrace 'rights defense' ultimately pose a serious political challenge to the assumptions underlying the Chinese regime. It is for this reason that the main advocates of a human-rights-centered political-legal structure in China have come under direct attack since the ascendance of Xi Jinping to power in 2012 - a subject that is reflected in many chapters in this book.

\section{Developments at the International Level}

Since 2008, China's external engagement with the international human rights system has become much more assertive and even aggressive in line with its growing economic and diplomatic clout to the point of potentially threatening to undermine existing norms and institutions.

In June 2017 and March 2018, the Human Rights Council adopted two resolutions sponsored by China that have prompted commentators to worry out loud about whether China's engagement with international human rights organizations is weakening the fundamental premises upon which the international institutions of human rights are based (Worden 2018). The first resolution adopted in June 2017; The contribution of development to the enjoyment of all human rights $A / H R C / 35 / L .33 / R e v .1$, emphasizes the centrality of 
development 'in facilitating the enjoyment of all human rights'.. ${ }^{1}$. This resolution directly incorporates the language used by Xi Jinping, adopted in the Report of the 19th Communist Party of China (CCP or Party) Congress in 2017 of 'building a community of shared future for human beings' into an official UNHRC Resolution. ${ }^{2}$

The second resolution on Promoting Mutually Beneficial Cooperation in the Field of Human Rights A/HRC/37/L.36 (March 2018) emphasize the pre-eminence of the state's right to development and a consultative approach to promoting human rights. It emphasizes cooperation between states to ensure sustainable and inclusive development. Some objections to this resolution express concern that promoting 'mutually beneficial cooperation', 'expanding common ground and strengthening constructive cooperation' seek to weaken established reporting and accountability mechanisms.

The official Chinese view of the significance of this resolution is captured by the statement issued by China's mission to the UN. ${ }^{3}$

...This is the first time that the concept of 'community of shared future for human beings' is incorporated into the Human Rights Council resolutions, officially making it an important part of the international human rights discourse....

On 1 March, at the 34th session of the Human Rights Council, China, on behalf of 140 countries, delivered a joint statement entitled 'Promote and Protect Human Rights, Build a Community of Shared Future for Human Beings', which explained the concept of 'a community of shared future for human beings' and its significance for promoting the international human rights cause. The statement resonated widely with the audience. The ideas of sovereign equality, dialogue and consultation, win-win cooperation, exchanges and mutual learning, and clean development included in the concept were well received and supported.

The concept of 'community of shared future for human beings' is adopted by the Human Rights Council resolutions as a result of the consensus of the international community. It also demonstrates China's growing influence and ability to set the agenda in international human rights governance. China will actively participate in and advance global human rights governance and promote the sustained and sound development of the international human rights cause, with the goal of building a 'community of shared future for human beings'.

These sentiments and priorities were embodied in the Beijing Declaration, adopted by the First South-South Human Rights Forum on 8 December 2017. ${ }^{4}$

The US voted against this resolution. ${ }^{5}$. Amongst the states that abstained, the Australian caution is representative. The official explanation of Australia's abstention notes that the resolution 'seeks to embed new, undefined concepts into human rights discourse' and that the 'language on technical assistance and capacity building lacks recognition of the

\footnotetext{
${ }^{1}$ www.unwatch.org/wp-content/uploads/2009/12/L.33-1.pdf.

${ }^{2}$ Full text of Xi Jinping's speech Work Together to Build a Community of Shared Future for Mankind delivered at the UN Office in Geneva 18 January 2017 is reproduced at http://www.xinhuanet.com/english/201701/19/c_135994707.htm.

${ }^{3}$ www.china-un.ch/eng/dbtyw/rqrd_1/speech/t1448593.htm.

${ }^{4}$ www.xinhuanet.com/english/2017-12/08/c_136811775.htm.

${ }^{5}$ US Mission to the UN Explanation of Position on Resolution on the Contribution of Development to the Enjoyment of all Human Rights 22 June 2017 https://geneva.usmission.gov/2017/06/23/explanation-of-positionon-resolution-on-the-contribution-of-development-to-the-enjoyment-of-all-human-rights-ahrc35l-33/.
} 
importance of monitoring, accountability and transparency, which help ensure international resources are utilized effectively'. 6

China's approach to locate the right to development, and so state sovereignty, at the center of all human rights and to weaken monitoring and accountability mechanisms is not new. Kinzelbach (2012) has documented from 2000 how China has sought consistently to advance these objectives and several contributors to this handbook (Kinzelbach, Muller, Kent) have noted that China has in fact adopted a consistent approach in this respect since publication of its first White Paper on Human Rights in China in 1991. ${ }^{7}$. The analysis of China's engagement with international agencies by contributions in this Handbook by Kinzelbach, Muller, Kent and Garwood-Gowers support a conclusion that China is now acting as a norm entrepreneur in that it is seeking to displace existing international treatment of issues of sovereignty and the right to development and monitoring and accountability.

China has in fact signaled its intention to take a more active role in shaping international norms, at least from October 2014. The Decision of the Party's 18th Congress Fourth Plenum (CCP Central Committee Decision Concerning Some Major Questions on Comprehensively Advancing the Country in Accordance with the Law) issued on 28 October 2014 sets this priority out clearly:

Vigorously participate in the formulation of international norms ... strengthen our country's discourse power and influence in international legal affairs, use legal methods to safeguard our country's sovereignty, security and development interests.

A common theme of chapters has been to document the active engagement of the Chinese Party-state with international norms of human rights; China as positioning itself to increasingly act as a norm maker while still being a norm taker in many spheres. The significance of this Handbook thus lies in its engagement with discussions of China's influence at the international level in shaping human rights norms and responsibilities of states as well as in its examination of the interpretation and implementation of international human rights norms and obligations within China.

\section{Domestic Themes}

There are several intersecting and overlapping themes that go beyond the boundaries of section headings, some of which are sketched below. The reader may find others.

\subsection{Law and practice}

A common theme that emerges from all chapters is the strain between legal, political and rhetorical promises of rights and their realization in practice. Contributors document the many programs and sometimes spectacular improvements achieved in the standard of living and social benefits enjoyed by Chinese citizens in areas including the right to health (Jacobs), poverty alleviation (Muller) and labor conditions (Elfstrom). Others document reforms to policy and law designed to improve and better protect rights in areas including the rights of children (Naftali), disability (Hallett), right to a fair trial (Nesossi), death penalty (Trevaskes), rights of women (Jiang) and mental health (Guo). Each notes the divergence, sometimes

\footnotetext{
${ }^{6}$ http://dfat.gov.au/international-relations/international-organisations/un/unhrc-20182020/statements/Documents/statement-on-promoting-mutually-beneficial-cooperation-in-the-field-of-hr-23march-2018.pdf.

${ }^{7}$ Information Office of the State Council of the People's Republic of China, Human Rights in China, available at www.china.org.cn/e-white/7/index.htm.
} 
small and sometimes large, between stated ambitions and actual results. This is a problem that is not unique to China, but it is important to document, as each of these chapters do, the particular ways and extents to which practice does not match the stated objective. In some areas, such as LGBTQ rights (Chia) the issue is less one of the gap between law, policy and practice than it is of silence and the absence of regulation.

\subsection{Development and rights}

Another tension lies in the mode of improvement of people's livelihoods. Is it as a consequence of development (flowing from and subject to the state's right to development), or an indicator of greater enjoyment of rights? As Muller's chapter points out, Philip Alston's report on his visit to China as Special Rapporteur on extreme poverty indicates an important distinction between benefits that might flow from successful developmental policies and programs and improvements in livelihood that are enjoyed as human rights. That lies in the availability of transparency and accountability mechanisms where citizens can obtain information about programs (improvements in this area are discussed in Horsley), have meaningful inputs into their formulation and demand accountability for failures. The 'meaningful access to accountability mechanisms' according to Alston, is key to the distinction between a development agenda and a rights agenda. ${ }^{8}$. In his report, Alston noted, in common with many chapters addressing social and economic rights in this volume, that there were few channels for citizens to engage in meaningful consultation in the formation of policies and limited capacity to complain about breaches of law or failures in policy. Jacobs' chapter on health discusses the distinction between entitlements or benefits, which are increasingly well protected, and freedoms, which are not.

In the area of citizen complaint making through administrative litigation, we see that despite recent legislative reform, challenging government decision-making in the courts continues to be difficult. The courts' jurisdiction is limited in scope (the court's jurisdiction to accept complaints is limited to an enumerated list at Administrative Litigation Law article 12) and does not fully extend to determining the lawfulness of subordinate or local regulations. The power of the courts to change administrative decisions remains comparatively limited. As the work of Biddulph (2015) documents, difficulties in accessing formal complaints mechanisms and the continuing low level of legitimacy of their decisions continues to encourage aggrieved citizens in the disputes relating to health, housing and labor to adopt informal, lesser-institutionalized and sometimes socially disruptive tactics in their pursuit of the justice they demand. Van Rooij (2012) shows how half-hearted embrace of legislated initiatives to allow citizen participation and improve their agency in complaint making in environmental law enforcement has had the perverse effect of exacerbating socially disruptive protest.

\subsection{Substantive topics and actors}

This volume has sought to include an examination of a wide range of topics that cover the so-called three generations of rights, civil and political, social and economic and group rights.

In our view a comprehensive discussion of human rights must not only engage with the topics of human rights, but also must pay attention to the processes and actors through whose actions rights are claimed, protected and advanced. As each chapter shows, the

\footnotetext{
${ }^{8}$ Report of the Special Rapporteur on extreme poverty and human rights on his mission to China, UN Doc A/HRC/35/26/Add.2, 28 March 2017.
} 
dominant actor in defining and promoting human rights is the Party-state. Successive human rights white papers and five-year human rights action plans document the centrally planned nature of the state's rights agenda. But 40 years of economic reform, accompanied by introduction of a 'socialist market economy with Chinese characteristics', has led to pluralization of society and the interests of China's citizens. A wide range of civil society organizations addressing the many and varied interests and agendas have become active where and when they have found space to do so. Even where there has not been political space, some have found a way to operate in the interstices of state control, all the time taking the risk of punishment or at least of having their activities shut down.

At the international level, China has moved to limit access of its own citizens and other independent social organizations who seek access to and voice in United Nations committees. One of the best known examples is case of human rights activist Cao Shunli, who died in custody after being detained in 2013 as she was preparing to travel to Geneva to participate in a human rights training program. At the domestic level, restrictions placed on the funding and operation of social organizations and passage in 2016 of the Law on the Management of the Domestic Activities of Foreign Non-governmental Organizations in China (also known as the Overseas NGO Law) have greatly restricted the space for civil society and social organizations.

The chapters in this volume that engage with the activities of non-state actors in human rights advocacy all document both the advances and challenges facing these individuals and groups in their advocacy work and in seeking redress for infringements of rights, or remedies for failures to deliver on rights promises. Lu Jun and Hallett describe the successes Chinese activists and civil society organizations have had in promoting antidiscrimination measures and legislation to protect the rights of those with disabilities. Elfstrom looks at the evolving nature of labor activism and its demands, tactics and organization. Grassroots public engagement in rights advocacy also factors in Brettell's chapter on environmental rights, Chia's chapter on LGBTQ activism and Jiang's chapter on women's rights and contemporary feminism in China. Fu Hualing, Teng Biao and many others highlight the role of rights defense lawyers.

These chapters also make clear that human rights advocacy at the grassroots level carries many risks and challenges, especially in an environment where, as Aubié, Datt and Beck, and others show, basic freedoms of expression, association and peaceful assembly are not adequately guaranteed. Collectively, these chapters should suggest to the reader the different ways and extents to which the Party-state is seeking to resist the challenge posed by Chinese citizens and social actors to its standard, authorized account of rule of law and human rights, as well as its determination to assert its own vision of the relationship between citizen and state.

\subsection{Impact of authoritarian political form and the stability imperative}

An important theme of this volume is to consider the impact of the authoritarian political form on the formulation and enjoyment of human rights in China. This point is raised and examined squarely in Pils's chapter, which argues that the case of China demonstrates that Rawls's argument that there can be a politically neutral approach to human rights is ultimately unsustainable. She argues that there is a fundamental liberal essence of rights and that that calls for (liberal) politics to be read back in to debates about and evaluations of human rights.

The dominance of a development-led approach to human rights naturally embraces the centrality of social and economic rights, even if the ways they are enjoyed is subordinated to and dependent upon state economic development. The approach also reflects a 
fundamental belief that the CCP, as a Leninist vanguard party, both leads and reflects the interests of the people. This vision obfuscates the reality that the interests of the Party-state and citizens are not and can never be synonymous or in harmony. Liberal notions of rights, and their premise that both the rule of law and human rights are designed to protect citizens against overbearing state power, remain conceptually in tension with Party orthodoxy.

Muller's chapter also touches on the impact of the authoritarian form of the Chinese polity as heightening its sensitivity to social and political instability. A consequence is that the Party-state's human rights policies and programs have social stability as both one of their criteria and their objectives (Biddulph 2015). Inevitably, we see a balancing of rights and order. The important questions that emerge for consideration are what view of rights and what view of order are officially sanctioned and how are rights and order balanced? There is no single answer to these questions, which differ over time and in relation to different subject matters.

At one level, this requirement for balancing is articulated in China's Constitution. The fundamental commitment to protecting human rights is asserted at article 33 which states that 'the state respects and protects human rights'. In setting out a wide range of fundamental rights of citizens, including civil and political rights, it also clearly places limits on these in the form of countervailing duties. Of importance in qualifying the enjoyment of civil and political rights are the duties of citizens not to infringe on the interests of the state, of society or the collective or upon the lawful freedoms and rights of other citizens (article 51), to safeguard the unity of the country (article 52), to safeguard the security, honor and interests of the motherland (article 54) and to defend the motherland and resist aggression (article 55).

As a result, there are natural limits placed on the freedom of expression guaranteed in article 35 and freedom of correspondence in article 40. Aubié's chapter documents the increasing use of prosecutions for the crime of endangering state security in response to forms of speech and communication that are unwanted or unacceptable to the Party-state. Svensson's chapter extends the discussion of protection of the rights of speech, expression and privacy in her analysis of systems for regulation of information and communication technologies. The chapters discussing freedom of assembly and demonstration (Datt and Beck) and freedom of movement (Xia) also provide powerful illustrations of the contingent nature of these rights and how they are inextricably linked to the Party-state's demand for order and stability.

Cook's chapter on freedom of religion considers how the Constitutional protection of religious freedom in China is immediately qualified by extending only to protect 'normal' religious activities. Regulation by the State Administration of Religious Affairs, as of March 2018 subsumed within the Party's United Front Work Department, plays an important role in determining how religious organizations function. Regulation is also a convenient vector for implementing changing policies of tolerance to different authorized religions.

The prevailing command and control approach to regulation, with its emphasis on top-down regulation and state-led enforcement and its implications for rights protection is particularly visible in the discussion of disability (Hallett), children's rights (Naftali) and women's rights (Jiang discusses the power of the model of state feminism).

\subsection{Differential impacts of strengthening 'governance capacity'}

The Decision Concerning Some Major Questions on Comprehensively Advancing the Country in Accordance with the Law, issued at the 4th Plenum of the 18th CCP Party Congress in October 2014, asserted that the strategy to strengthen the rule of law included strengthening governance as a primary objective. This policy has direct impact on human rights. 
First, it has driven legal and institutional reforms to improve the professionalism of the judiciary and government officials. Its aim has been to improve capacity and legitimacy of judicial and administrative decision making. Horsley has documented the expansion of open government information regulations and willingness of citizens to demand access to a wide range of information. The success of legal reforms such as improving protection of rights of people with mental health issues when they face administrative agencies and the criminal justice system, is discussed in Guo's chapter. Improving the quality of law enforcement is also deeply implicated in reducing abuses in the administration of criminal justice, particularly the death sentence (Trevaskes), ensuring a fair trial (Nesossi), reducing torture (Lewis) and arbitrary detention (Biddulph). However, as these chapters also demonstrate both the scope and content of law are also critical to achieving better outcomes for people detained within and outside the formal justice apparatus.

The second potential of strengthening rule of law, is that it provides an alternative to the existing vision of social stability, which is social quietude. That is if social and political stability derive from the stability of the system, then the need for strong repressive measures to be taken against protesters, dissenters and others engaged in socially disruptive protests is reduced. This is a vision of stability that Yu Jianrong has labelled flexible stability (Yu 2009).

\section{Political Dimensions of Human Rights in 'Greater China' and Beyond}

Though the bulk of this book deals with mainland China, we also wanted to include chapters touching on Hong Kong and Taiwan to illustrate how differently human rights is situated in those two parts of what some term 'Greater China'. Historically and culturally linked to the mainland, Hong Kong and Taiwan have followed their own distinctive development paths as a result of their colonial experiences (under British and Japanese rule, respectively) and, for Taiwan, decades under the authoritarian rule of the Kuomintang. Chen's chapter on Taiwan illustrates how, even though the Republic of China lost the ability to interact directly with the international human rights system after 1972, when its seat at the UN was given to the People's Republic of China, advocacy for human rights gave local Taiwanese opposition politicians a foothold to challenge authoritarianism and help usher in a transition to democracy in the 1990s. Since then, self-identification with human rights has given Taiwanese a way to measure their distinctiveness from mainland China, even if Taiwan still has many human rights issues to address. Similarly, Davis's chapter on Hong Kong illustrates how expectations about human rights and rule of law have become intertwined with political debates about Hong Kong's future as part of the People's Republic of China. As people in Hong Kong watch developments across the border and experience the growing influence of the mainland over their society and politics, many see commitment to the human rights guarantees that currently exist in Hong Kong to be the measure of the city's future.

Whilst the Handbook is very broad in scope, with chapters on 30 different topics, still we were not able to cover every single human rights issue. We were pleased to be able to include chapters on some emerging areas of human rights concern, including Svensson's chapter on the internet and Chia's chapter on LGBTQ rights. Potter's chapter illustrates how China's global trade and investment reflect and promote its state- and development-centered vision of human rights. There is much more that will inevitably be written on particular aspects of China's impact on human rights overseas, whether in terms of the impacts on the ground of Chinese overseas business operations or the impact that heavy amounts of debt owed to Chinese lenders for mega-infrastructure projects has on the ability of states to fulfil their health, education, housing and other human rights obligations. 
Brettell's chapter looks at China's response to the serious problem of global climate change, which is increasingly being recognized for its many linkages to human rights. As China looks to become a global leader in developing and producing technologies aimed at reducing carbon emissions, more attention needs to be paid to the extent to which those technologies and their associated supply chains may be contributing to negative human rights impacts elsewhere. Research has shown, for example, the many serious human rights abuses, including child labor, associated with the extraction of cobalt and other raw materials that go into the rechargeable lithium-ion batteries that power electric vehicles, renewable energy storage and other technologies used by people around the world. Unless the Chinese government and Chinese companies commit to robust human rights due diligence to identify, address and disclose these harms, the effort to address climate change risks exacerbating poverty and inequality in certain parts of the world.

Another area in which China is aiming to become a global leader is in the development and use of artificial intelligence (AI). The proliferation of AI technology and associated practices poses a number of serious challenges to human rights protection and governance that will need to be addressed. Surveillance technology, whether in the form of facial recognition cameras, voice analysis software or drones, is changing the way that states monitor and control their populations. China's main demonstration ground for this is in the Xinjiang Uyghur Autonomous Region in China's far northwest, where such technologies are being deployed on a massive scale to respond to what the authorities consider to be serious threats of terrorism and religious extremism by the region's Muslim populations. The unknown consequences of what some are calling a '21st century police state' are giving many people cause to worry about whether AI is allowing the power imbalance between states and individuals to grow unchecked and out of hand.

On this point, we should acknowledge that at the time this manuscript was being completed there was growing concern about the ongoing situation in Xinjiang, with credible reports of hundreds of thousands of ethnic Uyghurs, Kazakhs and other predominantly Muslim peoples being interned arbitrarily in so-called 'de-extremification' or 'transformation-through-education' camps. Given this situation, we deeply regret being unable to commission a chapter looking at the situation of the rights of ethnic minorities in China. We hope that the attention being paid to what is happening in Xinjiang, as well as Tibet, will lead to further examination of this complex and important subject and that such examination will contribute positively to making China a safe and prosperous place for all to live under the equal protection of human rights and the rule of law. 


\section{References}

Biddulph, Sarah (2015), The Stability Imperative: Human Rights and Law in China Vancouver: UBC Press.

Kinzelbach, Katrin (2012), 'Will China’s Rise Lead to a New Normative Order? An Analysis of Chinas' Statements on Human Rights at the United Nations (2000-2010)' 30(3)

Netherlands Quarterly of Human Rights, 299-332.

Nathan, Andrew J. (1986), Chinese Democracy, Berkeley: University of California Press. Svensson, Marina (2002), Debating Human Rights in China: A Conceptual and Political History, Lanham, MD: Rowman \& Littlefield.

Van Rooij, Benjamin (2012), 'The People’s Regulation: Citizens and Implementation of Law in China 25(2) Columbia Journal of Asian Law, 116-179.

Worden, Andrea (2018), 'With its Latest Human Rights Council Resolution, China Continues its Assault on the UN Human Rights Framework’ China Change 9 April. Accessed 18 September 2018 at chinachange.org/2018/04/09/with-its-latest-human-rights-councilresolution-china-continues-its-assault-on-the-un-human-rights-framework/.

Yu, Jianrong (2009), 'Rigid Stability: an explanatory framework for China's social situation', China Digital Times, 26 May 2009. Accessed 18 September 2018 at chinadigitaltimes.net/2009/05/yu-jianrong-rigid-stability-an-explanatory-framework-forchina\%E2\%80\%99s-social-situation-1/. 


\section{University Library}

\section{- M M I E R R A A gateway to Melbourne's research publications}

Minerva Access is the Institutional Repository of The University of Melbourne

Author/s:

Biddulph, S;Rosenzweig, J

Title:

Handbook on Human Rights in China

Date:

2019

Citation:

Biddulph, S. \& Rosenzweig, J. (2019). Handbook on Human Rights in China. (1), Edward Elgar Publishing.

Persistent Link:

http://hdl.handle.net/11343/252801 